\title{
ПСИХОФАРМАКОТЕРАПИЯ
}

\author{
УДК 616.89-008.441.13:615.03
}

Для цитирования: Шушпанова Т.В., Новожеева Т.П., Мандель А.И., Князева Е.М. Молекулярные мишени действия инновационного антиконвульсанта галодиф в терапии алкогольной зависимости. Сибирский вестник психиатрии и наркологии. 2018; 2 (99): 120-126. https://doi.org/10.26617/1810-3111-2018-2(99)-120-126

\section{Молекулярные мишени действия инновационного антиконвульсанта галодиф в терапии алкогольной зависимости}

\author{
Шушпанова Т.В. ${ }^{1}$, Новожеева Т.П. ${ }^{1}$, Мандель А.И. ${ }^{1}$, Князева Е.М. ${ }^{2}$ \\ ${ }^{1}$ Научно-исследовательский институт психического здоровья, Томский национальный исследовательский \\ медицинский центр Российской академии наук (НИИ психического здоровья Томский НИМЦ) \\ Россия, 634014, Томск, ул. Алеутская, 4 \\ ${ }^{2}$ Школа базовой инженерной подготовки Томского политехнического университета \\ Россия,634050, Томск, ул. Белинского, 55
}

\section{PEЗЮME}

Алкоголь вызывает нейропластические изменения бензодиазепиновых рецепторов, модулирующих ГАМК Р), поддерживающие алкогольную аддикцию. Изучение свойств бензодиазепиновых рецепторов (БДР) в мозге крыс Вистар с разным предпочтением к алкоголю показало, что аффинность связывания $\left[{ }^{3} \mathrm{H}\right]$ флунитразепама и $\left[{ }^{3} \mathrm{H}\right] \mathrm{Ro5}-4864$ во фракциях мембран была снижена, а плотность мест специфического связывания повышена в коре мозга «многопьющих» и «малопьющих» крыс по сравнению с «отвергающими» этанол животными. Введение антиконвульсанта мета-хлор-бензгидрилмочевины (галодифа) повышает аффинность бензодиазепиновых рецепторов в коре головного мозга у «многопьющих» крыс, что приводит к повышению нейромедиации ГАМК в мозге этих животных, вызывает снижение потребления алкоголя. Галодиф снижает экспрессию БДР плазматических мембран тромбоцитов крови больных алкоголизмом до уровня контрольных значений. Применение противосудорожных препаратов, влияющих на мишени действия алкоголя - БДР, и в частности галодифа, может обеспечить новый фармакотерапевтический подход к профилактике и лечению этого заболевания.

Ключевые слова: алкоголь, алкоголизм, антиконвульсант, $\gamma$-аминомасляная кислота, бензодиазепиновые рецепторы, мозг.

\section{ВВЕДЕНИЕ}

Механизм формирования алкогольной зависимости и возникновения синдрома отмены алкоголя еще недостаточно изучен и понятен, несмотря на большое количество данных экспериментальных и клинических исследований [1]. Алкоголизм является одной из форм импульсивного поведения у больных, обусловленной общим дефицитом торможения в поведении, или как результат нарушений, предвосхищающих негативные последствия алкоголизма. Нарушение процессов возбуждения и торможения в мозге может с высокой степенью риска являться основой развития алкоголизма. Возникновение рецидива у больных алкоголизмом часто связано с развитием тревоги при синдроме отмены хронического употребления этанола. Некоторые клинические симптомы, характерные для синдрома отмены алкоголя, являются общими среди пациентов с лекарственной зависимостью, вызванной злоупотреблением различных препаратов, в том числе бензодиазепинов [2, 3].

Исследования, проведённые на различных экспериментальных моделях животных, показали, что воздействие алкоголя приводит к снижению чувствительности к алкоголю и другим бензодиазепиновым агонистам $[2,4]$. Злоупотребление алкоголем вызывает развитие толерантности и зависимости, посредством взаимодействия этанола с ГАМК $\mathrm{A}_{\mathrm{A}} /$ бензодиазепиновым рецепторным комплексом (ГАМК $/$ БДР) в различных структурах головного мозга [5]. ГАМ$\mathrm{K}_{\mathrm{A}} /$ БДР - пентамерный макромолекулярный мембранный комплекс, имеющий места специфического связывания для многих лигандов: $\gamma$-аминомасляной кислоты (ГАМК), барбитуратов, бензодиазепинов, алкоголя и нейростероидов [6]. Предполагают, что умеренные дозы этанола действуют, непосредственно связываясь с белками, которые формируют

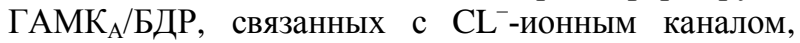
функция которого аллостерически модулируется в различных областях мозга, участвующих в развитии эффектов этанола. Антагонисты ГАМК способны препятствовать развитию эффектов этанола, ингибируя его седативное, анксиолитическое действие, а также подкрепляющий эффект этанола $[2,6]$. Изучение генетических факторов, влияющих на предрасположенность к алкогольной аддикции и развитие алкогольной зависимости у человека в различных популяциях, подтверждает роль гена, кодирующего $\alpha_{2}$-субъединицу ГАМК $/$ БДР, в чувствительности к острому воздействию алкоголя и развитию алкогольной зависимости [6, 7]. Исследование ГАМК $\mathrm{A} /$ БР в мозге у больных алкоголизмом в состоянии абстиненции с использованием позитронной и однофотонной эмиссионной компьютерной томографии, основанной на поглощении радиоактивных лигандов $\left[{ }^{11} \mathrm{C}\right]$ флюмазенила и $\left[{ }^{123} \mathrm{I}\right]$ иомазенила, показало снижение способности связывания рецепторов во фронтальной коре у этих пациентов 
[8], что может приводить к снижению ГАМКергической функции в мозге, нарушению процессов торможения в ЦНС и развитию синдрома отмены алкоголя.

Одной из ведущих проблем в лечении алкоголизма является необходимость формирования новых подходов к профилактике и лечению этого заболевания, поиск эффективных фармакологических средств коррекции, действующих на молекулярные мишени влияния алкоголя в ЦНС, способных препятствовать развитию алкогольной интоксикации и зависимости.

Инновационный противосудорожный препарат галодиф (мета-хлоро-бензгидрилмочевина) является производным гидантоина. В отличие от большинства аналогов, он сам является действующим веществом, не требующим трансформации в печени, что значительно (в 8-12 раз) снижает токсичность и исключает побочные эффекты (сонливость, гепатои нейротоксические эффекты). Результаты клинических испытаний показали высокую эффективность антиконвульсанта галодифа, обладающего широким спектром терапевтического действия.

Целью данного исследования было изучение влияния терапии с использованием оригинального инновационного антиконвульсанта галодифа на пластичность бензодиазепиновой рецепторной системы коры головного мозга крыс при экспериментальном алкоголизме и БДР тромбоцитов крови у больных алкоголизмом в качестве экстрацеребральной модели оценки эффективности проводимой терапии.

\section{МАТЕРИАЛ И МЕТОДЫ}

Эксперименты проводили на 250 крысах-самцах Вистар массой 150-200 г. Для изучения влияния оригинального антиконвульсанта м-хБГМ на потребление этанола и выраженность патологического влечения к нему животных тестировали на предпочтение (выраженность алкогольной мотивации) в условиях свободного выбора между $15 \%$ раствором этанола и водой в течение 14 суток (двухбутылочный оральный тест). Животных, предпочитавших этанол (уровень потребления составил более 50\%), делили на две группы: 1-я группа в течение 10 месяцев подвергалась принудительной алкоголизации (15\% раствор этанола в качестве единственного источника жидкости) - «многопьющие» крысы; 2-я группа не имела доступа к этанолу весь экспериментальный период - «малопьющие» крысы. Животные, у которых уровень потребления этанола был менее $10 \%$ от общего количества жидкости, составили группу «отвергавших» этанол (3-я группа) и содержались без доступа к этанолу весь период. По окончании экспериментального периода проводили повторное тестирование на предпочтение в группе «многопьющих» крыс и выделяли животных, не изменивших свое предпочтение к этанолу; животных, изменивших свое предпочтение, в эксперимент не включали. Таким образом, были отобраны крысы с высокой алкогольной мотивацией («многопьющие»).
Крыс всех экспериментальных групп распределяли на равные группы: одним группам, начиная с 15-х суток, вводили м-хБГМ в виде суспензии на $1 \%$ крахмальной слизи внутрижелудочно в дозе 100 мг/кг массы тела и регистрировали среднесуточное потребление $15 \%$ раствора этанола с последующим пересчётом на 96\% раствор этанола, другим (группы сравнения - контроль) вместо м-хБГМ вводили соответствующий объем $1 \%$ крахмальной слизи.

Для изучения бензодиазепиновой рецепторной системы мозга крыс с различным предпочтением к алкоголю и влияния м-хБГМ на бензодиазепиновую рецепторную систему мозга при экспериментальном алкоголизме часть крыс из всех исследуемых групп распределяли следующим образом: «многопьющие» крысы составили 1-ю группу; «малопьющие» - 2-ю группу; а «отвергавшие» этанол 3-ю группу; «многопьющие» крысы, получавшие мхБГМ в течение 14 суток, вошли в 4-ю группу.

Для проведения радиорецепторного анализа (РРА) свойств БДР в мозге крыс декапитировали под легким эфирным наркозом, мозг извлекали, кору головного мозга отделяли и замораживали в жидком азоте. Разделение образцов ткани мозга крыс на фракции мембран (синаптосом и митохондрий) проводили с помощью препаративного ультрацентрифугирования. Фракции мембран замораживали и хранили при $-80^{\circ} \mathrm{C}$. Свойства БДР исследовали методом РРА связывания синаптосомальных и митохондриальных мембран с селективными лигандами.

Свойства БДР «центрального» типа (ЦБР) коры мозга крысы изучали методом РРА связывания $\left[{ }^{3} \mathrm{H}\right]$ флунитразепама (85 Ки/моль; 0,2-15 нМ) с мембранами синаптосомальной фракции ткани мозга при $0^{\circ} \mathrm{C}$ в течение 60 минут. Концентрация мембран по белку составляла 0,2 мг/мл. Неспецифическое связывание проводили с флунитразепамом в концентрации 10 мкМ. Свойства БДР «периферического» типа (ПБР) коры мозга крысы исследовали методом PPA связывания [ $\left.{ }^{3} \mathrm{H}\right]$ Ro5-4864 (90 Ки/моль) с мембранами митохондриальной фракции коры головного мозга крысы.

Группу пациентов составили 68 мужчин в возрасте от 23 до 52 лет, страдавших алкоголизмом второй стадии (диагно3 по МКБ-10: F10.302; F10.232), при осложненных формах алкоголизма с коморбидным органическим поражением головного мозга, находившихся на лечении в клинике аддиктивных состояний НИИ психического здоровья ТНИМЦ РАН. Контрольную группу составили 20 здоровых мужчин-добровольцев.

Свойства БДР «периферического» типа (ПБР) тромбоцитов крови человека исследовали методом PРА связывания [ $\left.{ }^{3} \mathrm{H}\right]$ РК 11195 (90 Ки/моль). Радиоактивный анализ количества связанного лиганда проводили в сцинтилляционном бета-счетчике «Rack-beta» (LKB). Константу диссоциации (Kd) и максимальное число мест специфического связывания $\left(\mathrm{B}_{\max }\right)$ определяли методом анализа кривых 
насыщения в координатах Скэтчарда. Распределение признаков достоверно не отличалось от нормального, поэтому для статистической обработки данных применяли параметрический метод вариационной статистики (критерий Стьюдента) с использованием программы «Statistica 10.0».

Работу проводили в лаборатории клинической психонейроиммунологии и нейробиологии НИИ психического здоровья ТНИМЦ РАН (Томск), лаборатории физиологии, молекулярной и клинической фармакологии НИИ фармакологии и регенеративной медицины им. Е.Д. Гольдберга ТНИМЦ РАН (Томск) и лаборатории клинической биохимии НЦ психического здоровья РАН (Москва).

\section{РЕЗУЛЬТАТЫ И ИХ ОБСУЖДЕНИЕ}

Изучение свойств БДР в мозге крыс показало, что бензодиазепиновая рецепторная система головного мозга у крыс с разным отношением к этанолу имеет существенные различия. В коре головного мозга крыс, предпочитавших алкоголь, аффинность $(1 / \mathrm{Kd})$ БДР «центрального» (ЦБР) и «периферического» (ПБР) типов была достоверно снижена: у 1-й группы животных - в 1,7-2 раза, у 2-й - в 1,3-1,5 раза по сравнению с животными 3-й группы (рис. 1), что приводило к снижению чувствительности к алкоголю, способствовало развитию толерантности и формированию физической зависимости. Плотность рецепторов в коре головного мозга крыс 1-й и 2-й групп была повышена по сравнению с животными 3-й группы, причем наиболее существенные изменения выявлены для рецепторов «периферического» типа (150-160\%), что подтверждает большую степень ответа ПБР на интоксикационное и повреждающее действие этанола.

Галодиф эффективно снижал выраженность алкогольной мотивации у крыс, предпочитавших алкоголь, и оказывал модулирующее действие на бензодиазепиновую рецепторную систему головного мозга крыс 1-й группы («многопьющих»). В коре головного мозга крыс 1-й группы при хроническом воздействии $15 \%$ этанола галодиф повышал аффинность ЦБР и ПБР $(1 / \mathrm{Kd})$ (в $1,2-1,6$ раза соответственно, рис. 2), что приводило к увеличению нейромедиации ГАМК, вызывало снижение толерантности к алкоголю и уменьшение уровня его потребления. Галодиф вызывал тенденцию к снижению плотности $\left(\mathrm{B}_{\max }\right)$ ЦБР и ПБР в мозге крыс 1-й группы, приближая их значение к данным 3-й группы («отвергавших» этанол) (рис. 2), что свидетельствует о снижении экспрессии БДР, вызванной воздействием алкоголя.

Полученные нами результаты доказывают снижение аффинности БДР в коре головного мозга крыс, предпочитавших алкоголь. Это может свидетельствовать о том, что нейропластические адаптивные изменения БДР в мозге возникают раньше, чем формируется выраженное токсическое воздействие алкоголя на мозг $[5,8]$. Действие этанола может быть обусловлено разной экспрессией субъединиц ГАМК $\mathrm{A}$ [6].

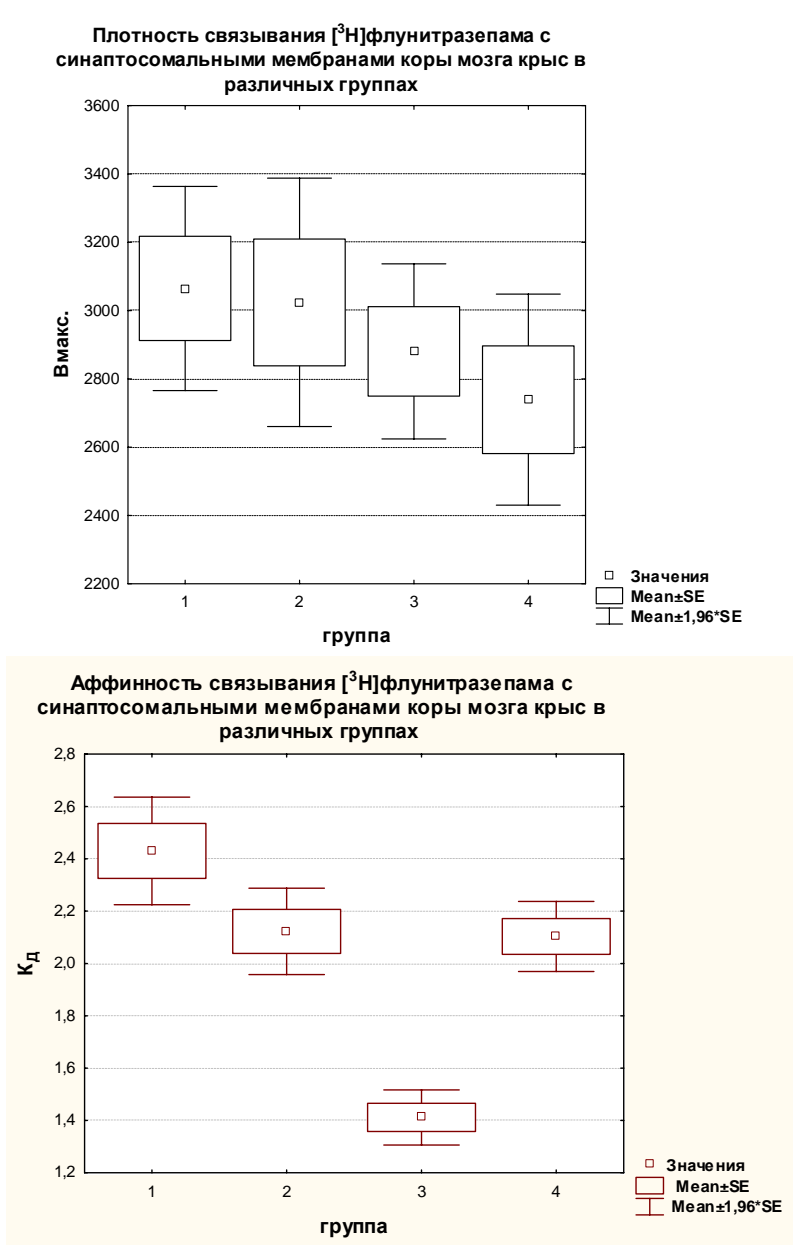

Р и с у н о к 1. Статистический анализ показателей плотности (а) и аффинности (б) связывания $\left[{ }^{3} \mathrm{H}\right]$ флунитразепама с синаптосомальными мембранами коры мозга крыс в различных экспериментальных группах

ГАМК $/$ БДР - пентамерный комплекс, состоящий из 5 белковых субъединиц, которые связаны с $\mathrm{Cl}^{-}$ионным каналом и являются, в основном, изоформами семейства $\alpha-, \beta-, \gamma$-субъединиц рецептора $[4,7]$.

Функциональные различия подтипов ГАМК $\mathrm{A}$ и их чувствительность к этанолу обусловлены изменчивостью в композиции субъединиц рецептора: изоформы $\gamma$-убъединицы $\gamma 2 \mathrm{~S}$ и $\mathrm{p}, \delta$ и $2 \gamma \mathrm{L}$ различаются по своей чувствительности к этанолу.

Хроническое употребление алкоголя вызывает разные нейроадаптивные изменения (индукцию нейропластичности) в ЦНС, приводит к изменению экспрессии и композиции субъединиц ГАМК ${ }_{\mathrm{A}} \mathrm{P}$, что связано с изменением их функционального вклада в процессы торможения в ЦНС и может играть существенную роль в адаптации к длительному воздействию этанола и в развитии толерантности $[4,9$, $10,11,15]$. Эти нейропластические изменения приводят к нарушению ГАМК-ергической функции, процессов торможения в мозге, что может обусловливать гипервозбудимость, включая судорожную активность при развитии алкогольного абстинентного синдрома. 
Нами установлено, что воздействие этанола вызывает изменение ПБР, не связанных с ГАМК $\mathrm{A}$, локализованных в митохондриальной мембране, в основном в глиальных клетках мозга, и обеспечивающих перенос холестерола внутрь митохондрий [14].

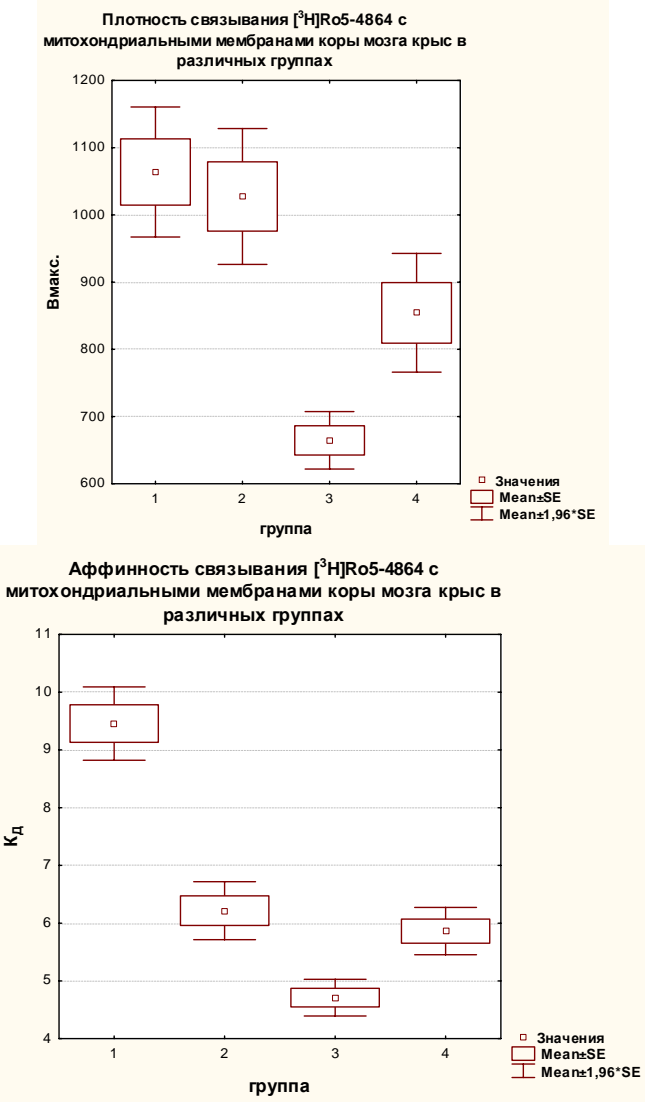

Р и с у н о к 2. Статистический анализ показателей плотности (a) и аффинности (б) связывания $\left[{ }^{3} \mathrm{H}\right]$ Ro54864 с митохондриальными мембранами коры мозга крыс в различных экспериментальных группах

Таким образом, ПБР влияют на регуляцию синтеза нейростероидов, являющихся эндогенными модуляторами ГАМК $/$ /БДР в ЦНС [9]. Бензодиазепины, анксиолитики, анестетики и алкоголь осуществляют некоторые эффекты через ПБР, регулируя продукцию нейростероидови их метаболитов, являющихся критичными компонентами нормальной функции мозга $[12,13,14]$. ПБР опосредованно влияют на ГАМК-ергическую функцию мозга, в основном реагируя на нейротоксическое воздействие и разные повреждения мозга.

Одной из ведущих является гипотеза развития толерантности к этанолу за счет усиления ГАМКдействия в эффектах этанола. Это подтверждает, что нечувствительность к этанолу может быть обусловлена сниженной чувствительностью к ГАМК и ГАМК-модуляторам. В результате исследований мы получили фактический материал, подтверждающий гипотезу о биологической детерминированности свойств БДР в коре головного мозга крыс с разным предпочтением этанола и однонаправленным изменением их под влиянием хронической алкоголизации.
Результаты наших исследований влияния галодифа на выраженность патологического влечения к этанолу у крыс в эксперименте свидетельствуют о терапевтической эффективности галодифа, связанной с его влиянием на функцию бензодиазепиновой рецепторной системы мозга. Влияние курсового применения препарата в течение 14 суток (100 мг/кг в сутки) приводит к изменению свойств БДР «центрального» и «периферического» типов. Причем в большей степени отмечено влияние на БДР михотондриальной локализации - ПБР, связанные с энергетическими и нейроэндокринными функциями нейронов и глии, что приобретает особое значение при нейротоксическом действии алкоголя. Галодиф повышал аффинность БДР к $\left[{ }^{3} \mathrm{H}\right]$ флунитразепаму и снижал компенсаторную экспрессию (плотность) рецепторов в коре головного мозга крыс при экспериментальном алкоголизме, что свидетельствует о повышении функции ГАМК $/$ БДР и, соответственно, ГАМК-нейротрансмиссии, нормализующей баланс возбуждающей и ингибиторной функций мозга. Аналогичные изменения выявлены при изучении связывания селективного лиганда $\left[{ }^{3} \mathrm{H}\right] \mathrm{Ro} 5-$ 4864 с БДР «периферического типа» в коре мозга крыс, регулирующих экспрессию нейроактивных стероидных гормонов под влиянием терапии. Повышение чувствительности ГАМК $/$ БДР-комплекса под влиянием галодифа может быть следствием более эффективной функциональной связи активных сайтов рецепторного комплекса: БДР и хлорного канала, препарат можно рассматривать в качестве позитивного аллостерического модулятора БДР.

Результаты исследования клинической эффективности галодифа у больных алкоголизмом выявили антиконвульсивный, аналгезирующий и седативный эффекты и были рекомендованы авторами для применения как в стационарах, так и в амбулаторных условиях в качестве противорецидивного и профилактического средства в лечении алкоголизма. Кроме того, был выявлен целый ряд дополнительных ценных свойств препарата: галодиф обладает антиоксидантным, ноотропным, антиаритмическим, дегидратирующим и антигипоксическим свойствами. Курсовое применение оригинального антиконвульсанта галодиф в течение 21 дня в суточной дозе 300 мг (по 100 мг 3 раза в день) у больных в абстинентном и постабстинентном состоянии вызывало редукцию выраженности симптомов, характерных для синдрома отмены алкоголя. Галодиф оказывал выраженное вегетостабилизирующее, нормолептическое, аналгезирующее действие, а также проявлял устойчивый лечебный эффект за счёт снижения выраженности симптомов синдрома отмены алкоголя и патологического влечения к этанолу. Сравнительный анализ плотности БДР плазматических мембран тромбоцитов крови показал достоверное повышение плотности БДР $\left(\mathrm{B}_{\max }\right)$ у больных алкоголизмом по сравнению со здоровыми добровольцами. 
Терапия галодифом приводила к снижению экспрессии БДР, модулирующих функцию ГАМК $\mathrm{A}^{-}$ рецепторов, что выражалось в снижении плотности рецепторов тромбоцитов крови у больных алкоголизмом до уровня контрольных значений у здоровых добровольцев (рис. 3).

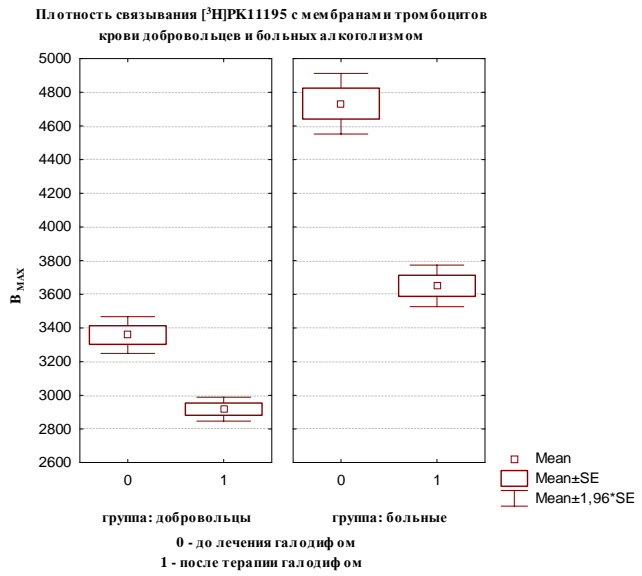

Р и с у н о к 3. Статистический анализ плотности связывания [ $\left.{ }^{3} \mathrm{H}\right]$ PK11195 (Bmax) с мембранами тромбоцитов крови больных алкоголизмом и добровольцев до и после терапии галодифом

Экспрессия рецепторов - плотность БДР тромбоцитов - экстрацеребральный показатель нейропластических изменений в ЦНС, лежащих в основе развития патологического влечения к алкоголю и аддикции.

\section{ЗАКЛЮЧЕНИЕ}

Нами показана эффективность терапии с использованием оригинального антиконвульсанта галодиф у больных с выраженным компульсивным влечением к алкоголю, ассоциированным с изменением экспрессии БДР тромбоцитов крови, используемой в качестве экстрацеребральной модели оценки нейропластических изменений под влиянием хронического воздействия алкоголя и терапевтической эффективности фармакологических препаратов.

Перспективы лечения алкогольной аддикции связаны с использованием новых препаратов, оказывающих модулирующее действие на ГАМК /бензодиазепиовые рецепторы, стимулирующих ГАМК-медиацию, проявляющих анксиолитические свойства без выраженного седативного эффекта, не формирующих зависимость и синдром отмены при их использовании $[15,16]$. В этой связи применение противосудорожных препаратов, влияющих на мишени действия алкоголя - БДР, и в частности галодифа, может обеспечить новый фармакотерапевтический подход к профилактике и лечению этого заболевания [17].

\section{КОНФЛИКТ ИНТЕРЕСОВ}

Авторы заявляют об отсутствии конфликта интересов в связи с публикацией данной статьи.

\section{ИСТОЧНИК ФИНАНСИРОВАНИЯ}

Статья подготовлена в рамках поисковых научных исследований «Разработка методов персонализированной терапии у больных аддиктивными расстройствами». Шифр темы 0550-2016-0401. Номер госрегистрации АААА-А16-116042610053-7.

\section{СООТВЕТСТВИЕ ПРИНЦИПАМ ЭТИКИ}

Исследование одобрено этическими комитетами НИИ психического здоровья и НИИ фармакологии и регенеративной медицины им. Е.Д. Гольдберга ТНИМЦ РАН.

\section{ЛИТЕРАТУРА}

1. Анохина И.П. Основные биологические механизмы зависимости от психоактивных веществ. Наркология: национальное руководство / под ред. Н.Н. Иванца, И.П. Анохиной, М.А. Винниковой. М.: ГЭОТАР-Медиа, 2008.

2. Балашов А.М. Система ГАМК и алкоголь: существует ли «этанольный рецептор»? (обзор). Журнал неврологии и психиатрии им. С.С. Корсакова. Алкоголизм. Приложение к журналу. 2007; 1: 56-62.

3. Бохан Н.А., Мандель А.И. Старые и новые проблемы наркологии в контексте междисциплинарных исследований. Вoпросы наркологии. 2017; 1: 26-62.

4. Criswell H.E., Breese G.R. A conceptualization of integrated actions of ethanol contributing to its GABA mimetic profile: a commentary. Neuropsychopharmacology. 2005; 30: 1407-1425.

5. Collingridge G.L., Isaac J.T., Wang Y.T. Receptor trafficking and synaptic plasticity. Nature Reviews. Neuroscience. 2004; 5: 952-962.

6. Mehta A.K. Ticku M.K. Effect of chronic administration of ethanol on $\mathrm{GABA}(\mathrm{A})$ receptor assemblies derived from alpha2-, alpha3, beta2- and gamma2-subunits in the rat cerebral cortex. Brain Res. 2005; 1031 (1): 134-137.

7. Li D., Sulovari A., Cheng C., Zhao H., Kranzler H.R., Gelernter J. Association of gamma-aminobutyric acid A receptor $\alpha 2$ gene (GABRA2) with alcohol use disorder. Neuropsychopharmacology. 2014; 39 (4): 907-918.

8. Goldstein R.Z., Volkow N.D. Dysfunction of the prefrontal cortex in addiction: neuroimaging findings and clinical implications. Nat. Rev. Neurosci. 2008; 12: 652-669.

9. Шушпанова Т.В., Солонский А.В. Синаптогенез и формирование бензодиазепиновых рецепторов мозга человека в условиях пренатальной алкоголизации. Журнал неврологии и психиатрии им. С.С. Корсакова. 2012; 1 (112): 60-67.

10. Shushpanova T.V., Solonskii A.V. Synaptogenesis and the formation of benzodiazepine receptors in the human brain in conditions of prenatal alcoholization. Neurosci Behav Phisiol. 2013; 43 (4): 423-430.

11. Shushpanova T.V., Bokhan N.A., Lebedeva V.F., Solonskii A.V., Udut V.V. The effect of chronic alcohol abuse on the benzodiazepine receptor system in various areas of the human brain. African J Psychiatry. 2016; 19 (3):1000365 doi: 10.4172/23785756.1000365

12. Papadopolous V., Baraldi M., Guilarte T. R. et al. Translocator protein $(18 \mathrm{kDa})$ : New nomenclature for the peripheral-type benzodiazepine receptor based on its structure and molecular function. Trends Pharmacol. Sci. 2006; 27: 402-409.

13. Шушпанова Т.В., Семке В.Я. Периферические бензодиазепиновые рецепторы тромбоцитов при алкоголизме. Журнал неврологии и психиатрии им. С. С. Корсакова. 2006; 11 (106): 53-56.

14. Shushpanova T., Bokhan N., Novozheyeva T. Density of thrombocyte benzodiazepine receptors and levels of neuroactive steroid hormones in alcoholic patients. European Neuropsychopharmacology. 2013. 23 (Suppl 2): S555 (P.6.a.005)

15. Shushpanova TV. Influence of maternal alcoholism on the brain benzodiazepine receptor in human embryo and fetus during ontogeny. .J of Alcohol \& Drug Depend. 2014; 2: 176. doi: 10.4172/2329-6488.1000176

16. Markova E., Knyazeva M., Kozlov V. Applied and Fundamental Studies: Proceedings of the 1st International Academic Conference. October 27-28, 2012; St. Louis, Missouri, USA. 2012: 21-26. 
17. Шушпанова Т.В., Семке В.Я., Солонский А.В., Бохан Н.А., Удут В.В. Бензодиазепиновая рецепторная система мозга человека и крысы в развитии алкогольной аддикции. Журнал неврологии и психиатрии им. С.С. Корсакова, 2014; 5 : $50-54$.

Шушпанова Тамара Владимировна, к.м.н., ведущий научный сотрудник лаборатории клинической психонейроиммунологии и нейробиологии.

Новожеева Татьяна Петровна, д.м.н., старший научный сотрудник лаборатории клинической психонейроиммунологии и нейробиологии. Мандель Анна Исаевна, д.м.н., профессор, ведущий научный сотрудник отделения аддиктивных состояний.

Князева Елена Михайловна, доцент школы базовой инженерной подготовки Томского политехнического университета.

Шушпанова Тамара Владимировна, shush59@ mail.ru

УДК 616.89-008.441.13:615.03

For citation: Shushpanova T.V., Novozheeva T.P., Mandel A.I., Knyazeva E.M. Molecular targets of action of innovative anticonvulsant galodif in therapy of alcohol dependence. Siberian Herald of Psychiatry and Addiction Psychiatry. 2018; 2 (99): 120-126. https://doi.org/10.26617/1810-3111-2018-2(99)-120-126

\title{
Molecular targets of action of innovative anticonvulsant galodif in therapy of alcohol dependence \\ Shushpanova T.V. ${ }^{1}$, Novozheeva T.P. ${ }^{1}$, Mandel A.I. ${ }^{1}$, Knyazeva E.M. ${ }^{2}$
}

\author{
${ }^{1}$ Mental Health Research Institute, Tomsk National Research Medical Center, Russian Academy of Sciences \\ Aleutskaya Street 4, 634014, Tomsk, Russian Federation \\ ${ }^{2}$ School of Basic Engineering Training of Tomsk Polytechnic University \\ Belinsky Street 55, 634050, Tomsk, Russian Federation
}

\section{ABSTRACT}

Alcohol causes neuroplastic changes in benzodiazepine receptors, modulating GABA-receptors $\left(\mathrm{GABA}_{\mathrm{A}} \mathrm{R}\right)$, which support alcohol addiction. The study of the properties of benzodiazepine receptors (BDR) in the brains of Wistar rats with different preferences for alcohol shows that the affinity of binding of $\left[{ }^{3} \mathrm{H}\right]$ flunitrazepam and $\left[{ }^{3} \mathrm{H}\right]$ Ro5-4864 in membrane fractions is reduced, and the density of specific bindings it is increased in the cerebral cortex of "multi- and "low-drinking" rats in comparison with "rejecting" ethanol animals. The introduction of an anticonvulsant meta-chloro-benzhydrylurea (galodif) increases the affinity of benzodiazepine receptors in the cerebral cortexin of "multi-drinking" rats, which leads to an increase in GABA neurotransmission in the brain of these animals, causing a decrease in alcohol consumption. Galodif reduces the expression of BDR plasma membranes of blood platelets in patients with alcoholism to the level of control values. The use of anticonvulsant drugs that affect the target of alcohol - BDR, and in particular galodif, can provide a new pharmacotherapeutic approach to prevention and treatment of this disease.

Keywords: alcohol, alcoholism, anticonvulsant, $\gamma$-amino butyric acid, benzodiazepine receptors, brain.

\section{REFERENCES}

1. Anokhina I.P. Osnovnyie biologicheskie mehanizmyi zavisimosti ot psihoaktivnyih veschestv. Narkologiya: natsionalnoe rukovodstvo [Main biological mechanisms of substance dependence. Narcology: National Handbook]. N.N. Ivanets, I.P. Anokhina, M.A. Vinnikova, eds. M.: GEOTAR-Media, 2008 (in Russian).

2. Balashov A.M. Sistema GAMK i alkogol: suschestvuet li «etanolnyiy retseptor»? (obzor) [GABA system and alcohol: does "ethanol receptor" exist? (review). Zhurnal nevrologii $i$ psihiatrii im. S.S. Korsakova - S.S. Korsakov Journal of Neurology and Psychiatry. Alkogolizm. Prilozhenie k zhurnalu [Alcoholism. Supplement to journal]. 2007; 1: 56-62 (in Russian).

3. Bokhan N.A., Mandel A.I. et al. Staryie i novyie problemyi narkologii $\mathrm{v}$ kontekste mezhdistsiplinarnyih issledovaniy [Old and new issues of addiction medicine in the context of interdisciplinary research]. Voprosyi narkologii - Journal of Addiction Problems. 2017; 1: 26-62 (in Russian).

4. Criswell H.E., Breese G.R. A conceptualization of integrated actions of ethanol contributing to its GABA mimetic profile: a commentary. Neuropsychopharmacology. 2005; 30: 1407-1425.

5. Collingridge G.L., Isaac J.T., Wang Y.T. Receptor trafficking and synaptic plasticity. Nature Reviews. Neuroscience. 2004; 5: 952-962.

6. Mehta A.K., Ticku M.K. Effect of chronic administration of ethanol on GABA(A) receptor assemblies derived from alpha2-, alpha3, beta2- and gamma2-subunits in the rat cerebral cortex. Brain Res. 2005; 1031 (1): 134-137.
7. Li D., Sulovari A., Cheng C., Zhao H., Kranzler H.R., Gelernter J. Association of gamma-aminobutyric acid A receptor $\alpha 2$ gene (GABRA2) with alcohol use disorder. Neuropsychopharmacology. 2014; 39 (4): 907-918.

8. Goldstein R.Z., Volkow N.D. Dysfunction of the prefrontal cortex in addiction: neuroimaging findings and clinical implications. Nat. Rev. Neurosci. 2008; 12: 652-669.

9. Shushpanova T.V., Solonsky A.V. Sinaptogenez i formirovanie benzodiazepinovyih retseptorov mozga cheloveka $v$ usloviyah prenatalnoy alkogolizatsii [Synaptogenesis and formation of benzodiazepine receptors in the human brain in conditions of prenatal alcoholization]. Zhurnal nevrologii i psihiatrii im. S.S. Korsakova - S.S. Korsakov Journal of Neurology and Psychiatry. 2012; 1 (112): 60-67 (in Russian).

10. Shushpanova T.V., Solonskii A.V. Synaptogenesis and the formation of benzodiazepine receptors in the human brain in conditions of prenatal alcoholization. Neurosci Behav Phisiol. 2013; 43 (4): 423-430

11. Shushpanova T.V., Bokhan N.A., Lebedeva V.F., Solonskii A.V., Udut V.V. The effect of chronic alcohol abuse on the benzodiazepine receptor system in various areas of the human brain. African J Psychiatry. 2016; 19 (3):1000365 doi: 10.4172/23785756.1000365

12. Papadopolous V., Baraldi M., Guilarte T. R. et al. Translocator protein $(18 \mathrm{kDa})$ : New nomenclature for the peripheral-type benzodiazepine receptor based on its structure and molecular function. Trends Pharmacol. Sci. 2006; 27: 402-409. 
13. Shushpanova T.V., Semke V.Ya. Perifericheskie benzodiazepinovyie retseptoryi trombotsitov pri alkogolizme [Peripheral benzodiazepine receptors of thrombocytes in alcoholism]. Zhur nal nevrologii i psihiatrii im. S. S. Korsakova - S.S. Korsakov Journal of Neurology and Psychiatry. 2006; 11 (106): 53-56 (in Russian).

14. Shushpanova T., Bokhan N., Novozheyeva T. Density of thrombocyte benzodiazepine receptors and levels of neuroactive steroid hormones in alcoholic patients. European Neuropsychopharmacology. 2013. 23 (Suppl 2): S555 (P.6.a.005)

15. Shushpanova TV. Influence of maternal alcoholism on the brain benzodiazepine receptor in human embryo and fetus during ontogeny. J of Alcohol \& Drug Depend. 2014; 2: 176. doi: 10.4172/2329-6488.1000176
16. Markova E., Knyazeva M., Kozlov V. Applied and Fundamental Studies: Proceedings of the 1st International Academic Conference. October 27-28, 2012; St. Louis, Missouri, USA. 2012: 21-26.

17. Shushpanova T.V., Semke V.Ya., Solonsky A.V., Bokhan N.A., Udut V.V. Benzodiazepinovaya retseptornaya sistema mozga cheloveka i krysy v razvitii alkogol'noy addiktsii [Brain benzodiazepine receptors in humans and rats with alcohol addiction]. Zhurnal nevrologii i psikhiatrii imeni S.S. Korsakova S.S. Korsakov Journal of Neurology and Psychiatry. 2014; 5: 50-54 (in Russian).

Received February 2.2018 Accepted April 2.2018

Shushpanova Tamara V., PhD, lead researcher of the Laboratory of Clinical Psychoneuroimmunology and Neurobiology, Mental Health Research Institute, Tomsk National Research Medical Center, Russian Academy of Sciences, Tomsk, Russian Federation.

Novozheeva Tatyana P., MD, senior researcher of the Laboratory of Clinical Psychoneuroimmunology and Neurobiology, Mental Health Research Institute, Tomsk National Research Medical Center, Russian Academy of Sciences, Tomsk, Russian Federation.

Mandel Anna I., MD, Prof., lead researcher of Addictive States Department, Mental Health Research Institute, Tomsk National Research Medical Center, Russian Academy of Sciences, Tomsk, Russian Federation.

Knyazeva Elena M., senior lecturer, School of Basic Engineering Training of Tomsk Polytechnic University, Tomsk, Russian Federation.

Shushpanova Tamara V., shush59@mail.ru 